accepted by the British Government, who have appointed additional members to the Commission. The terms of reference of the Commission are : To study and report upon the suitability and practicability of large-scale colonization in British Guiana for involuntary emigrants of European origin, from the physical, climatic and econornic points of view; to estimate the approximate numbers that might be settled there $(a)$ immediately, $(b)$ over a term of years; to calculate the probable cost of such settlement: if mass colonization appears feasible, to recommend a general plan of settlement. The names of the members are: Dr. Edward C. Ernst, assistant director, Pan-American Sanitary Bureau (chairman); Colonel Howard U. Nicholas, United States Army Engineering Corps, Panama Canal ; Dr. Joseph A. Rosen, Jewish colonization expert and agronomist; Mr. Emile C. Bataille, colonization expert with Canadian experience; Dr. Anthony Donovan, sanitary engineer; Mr. Desmond Holdridge, who has previous experience of the Colony (secretary). Sir Crawford Douglas-Jones, formerly Colonial Secretary of British Guiana; Sir Geoffrey Evans, formerly principal of the Imperial College of Tropical Agriculture, Trinidad, now economic botanist at the Royal Botanic Gardens, Kew. Dr. D. W. Duthie, agricultural chemist to the British Guiana Government, is being attached to the Commission for the purpose of advising and co-operating with the Commission.

\section{Science and World Resources}

THE December issue of Fact (No. 21. 6d.) contains a study "Science and World Resources" by Richard Palmer, which gives a comprehensive but readable survey of the way in which the world economy is changing under the impact of scientific advance. Mr. Palmer gives a dynamic picture of the way in which scientific discoveries and their technical development from synthetic dyes such as indigo and alizarin to synthetic rubber, the new textile fibres such as rayon and more recently 'Lanital' and 'Nylon' and the numerous synthetic resins or plastics, are influencing not merely the development of new industries or the displacement of old industries but also the distribution and availability of materials in the world, the location of industry, etc. Mr. Palmer's survey ranges over the whole field of materials, including beet sugar, alcohol, petroleum, coal, fertilizers, and light metals, and indicates admirably even to the non-technical reader the new freedom which the organic chemist is giving us and some of the possibilities if the new powers and opportunities are wisely used. Other chapters range over the possibilities in the way of power production which we owe to science and their significance in world economy, as well as the possibilities in agriculture and the way in which science has made it possible to improve working conditions and thus both industrial efficiency and the climatic or geographical zones within which effective production by human beings is possible. The essay provides an excellent background against which to discuss such current problems as those of raw materials and their bearing on the colonial question, the limits of self-sufficiency policies, sanctions, economic nationalism and the like. The realistic picture he gives enforces the necessity for strengthening, while there is yet time, our efforts to create a social and international order in which knowledge will be used to the full in the service of all mankind.

\section{The Empire Service Broadcasting Station}

Mr. L. W. Hayes and Mr. R. N. MacLarty presented an interesting paper to the Institution of Electrical Engineers on February 2. They first gave an account of how broadcast transmissions with short waves initially started at the Chelmsford works of Marconi's Wireless Telegraphic Co. in 1927. This gave intelligible reception at practically every place on the earth's surface at almost every period of the day and year. A serious difficulty that had to be overcome was due to the wide difference in longitude of the different Dominions and Colonies of the British Empire. For this reason, a transmission sent out at a given time in England would arrive at very various local times of the night and day in the different Dominions. Broadly, the aim of the service is to give listeners anywhere in the Empire a daily programme of about two hours' duration; the installation of the new broadcasting service started in 1933 practically does this. Earlier than this, reports received in the West Indies also gave a service at the same time in Western Australia, and the announcement of "London calling the African and West African Zones" was being heard simultaneously at night in Africa, in the early evening in South America and the West Indies, and at breakfast time in New Zealand. This showed that dividing the earth into geographical zones could cause confusion. Accordingly, the daily transmission from the Empire Station at Daventry was divided into five sessions: Transmission No. 1, Transmission No. 2, etc., in accordance with a time schedule, the programme from the first zone being recorded and then transmitted at the most suitable times to the other zones. In 1935 , a sixth transmission was added, primarily intended for evening listening in western Canada, but serving also North America generally and giving an early morning service to India.

\section{Conditions of Engineering Contracts}

THE subject-matter of an engineering contract necessitates that the documents of which the contract is composed must make provision for contingencies and events of a special nature. In this respect, it has peculiarities not to be found in other forms of contract, and is often inevitably of considerable length. The Council of the Institution of Civil Engineers asked Mr. E. J. Rimmer to write a paper on the subject which will be discussed by correspondence until May 15. The Council gave the author of this paper a very wide discretion in the choice of the title and in the scope of the paper. He has wisely chosen to give a comprehensive survey of the whole subject of engineering contracts. Many engineering contract works are to be constructed in, or erected and fixed on to, land. They cannot, therefore, be rejected and sent back to the contractor 